\title{
A Review of Design and Material Selection for a Hybrid Vehicle
}

\author{
Sudipto Shekhor Mondol ${ }^{1}$, Saswata Ghosh ${ }^{2}$ \\ ${ }^{1}$ Department of Mechanical Engineering, Heritage Institute of Technology \\ ${ }^{2}$ Department of Mechanical Engineering, Dr. Sudhir Chandra Sur Degree Engineering College
}

\begin{abstract}
Hybridization in automobiles can be regarded as a significant step in reducing greenhouse gases and harmful emissions. In the modern era, where gasoline powered vehicles are ruling the automotive industry; the technology of hybrid vehicles may reduce the consumption of fuel and become one of the most important eco-friendly technology in the near future. Further development of hybrid vehicles should be encouraged to reduce dependency on fossil fuel. This paper describes the design and fabrication procedures that were undertaken for the manufacture of a hybrid vehicle and a brief idea of alternate materials that were used and what could have been used instead.
\end{abstract}

Keywords: Hybrid Vehicle, automobiles, manufacturing, material selection, design, ecofriendly, Solid Works

\section{Introduction}

With growing awareness of environmental and economic impacts linked to excessive consumption of fuels by the transport sector, the world is now more focused on sustainable technologies like never before. Various ecodesign engineering practices and selection of the correct material for its manufacture can reduce energy consumption to a great extent. Any vehicle which has a two or more power source can be termed as a hybrid vehicle. These vehicles are efficient than the conventional ones because it reduces tailpipe emissions and increases mileage.

The most common type of hybrid vehicle is the gasolineelectric hybrid vehicle. In this type of vehicle, gasoline (petrol) is used along with electric batteries for the energy used to power internal-combustion engines and electric motors respectively. One may even categorize a mo-ped (a motorized pedal bike) as hybrid vehicle since it combines the power of gasoline engine with the pedal power of the rider.

The biggest trends in automobile engineering at this point of time are improving engine efficiency and fuel economy. Hybrid cars are making a good reputation in the markets. Car companies have great hopes that hydrogen will someday replace hydrocarbons and power cars which do not harm the environment. Pressurized hydrogen combines with oxygen in layers of thin membranes called fuel cells. The hydrogen atoms are broken apart which releases electrons that flow through a circuit which provides the electricity that propels the vehicle and the only emission is water vapor. Tesla Motors has developed cars which are solely powered by electricity. Diesel electric military tech demonstrators such as the AHED 8x8 has also came into existance. All the F1 cars since 2014 are hybrids. Apple is currently working with a number of developers in making more car-friendly apps. Volvo, BMW and Mercedes-Benz are going to unleash 'talkative' models early. The idea behind this technology is to communicate between cars. With the help of this idea, the cars will be able to sense any obstructions and potential hazards way before humans can. Electric drive systems are the future of the automobile industry but internal combustion engines still remains as an essential component of a vehicle.

A downsized and turbocharged engine is used more often than the non- downsized engines, because it has a significant increase in fuel efficiency. Downsized engines are lighter, thus, reducing vehicle mass and improving fuel economy. Turbochargers increases power-to-displacement ratio by recovering the energy from exhaust gases. Another research is being made to increase the efficiency of internal combustion engines by introducing several new modes in it, the latest being HCCI (homogeneous charge compression ignition). This aims at combining the advantages of modern diesel and gasoline combustion processes.

\section{Working of A Hybrid Vehicle}

The hybrid car has a fuel tank which supplies gasoline to the engine, which transfers rotary motion to the transmission system and turns the wheels. It also has a set of batteries which powers the electric motor, the motor runs the transmission system. The Engine and the Motor run the transmission system independently.

When the car idles, it uses electricity instead of wasting petrol and spewing fumes.

The engine is used at speeds when it's most efficient. While accelerating or going uphill, the extra power needed is provided by batteries. The batteries are charged by an alternator driven by the engine. However, the hybrid vehicle, in our current study, is not equipped with any battery recharging facility. Thus, in spite of having a small engine, hybrid vehicles provide high efficiency and mileage and adds to the advantage of the hybrid car.

The electrical components used in hybrid car are:-

\section{Volume 5 Issue 10, October 2016 www.ijsr.net}




\section{International Journal of Science and Research (IJSR) \\ ISSN (Online): 2319-7064 \\ Index Copernicus Value (2013): 6.14 | Impact Factor (2015): 6.391}

\subsection{Start/Stop Button}

The Start/Stop button, which helps in ignition of the vehicle during the start and also when it comes to a stop.

\subsection{Electric Drive}

In heavy traffics, when the car has to stop multiple times only the electric motor supplies power to the car.

\subsection{Electric assisted drive}

In highways, when the vehicle speed is high, the electric motor works along with the gasoline engine to provide the extra power.

\subsection{Regenerative Braking}

While braking, the kinetic energy, which in case of a mechanical brake is dissipated as heat, is used up the hybrid

Figure 3.1: Chassis Design in SolidWorks

All the different elements of the car were designed separately in SolidWorks part documents and then they were assembled together in a SolidWorks assembly document. Some of the SolidWorks part documents of the hybrid vehicle components are as follows: cars to recharge the batteries when the electric motor works as generator.

\subsection{Power-split Device}

This is the main component of hybrid car. It consists of a gearbox, which connects the gasoline engine, generator, and electric motor together by a "planetary gear system" and allows it to work like a parallel hybrid. The Hybrid Vehicle Power Train Configurations are Parallel hybrid, Mid Parallel hybrid, Power-split or Series Parallel hybrid, Series hybrid and Plug-in hybrid (PHEVs).

\section{Hybrid Vehicle Design Procedure}

The whole project of manufacturing a hybrid vehicle took nearly a month. First, the design of the vehicle was realized using SolidWorks CAD software.
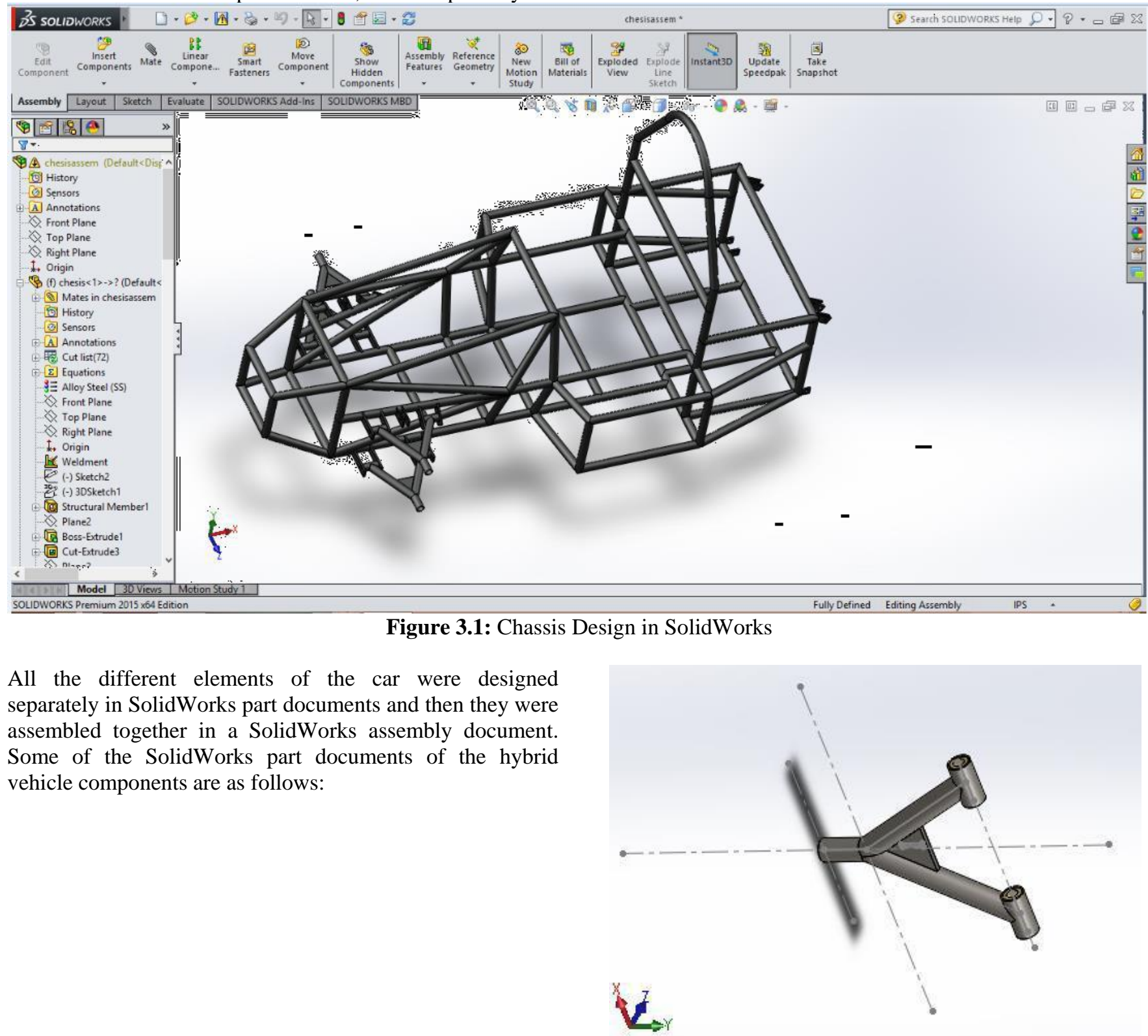

Figure 3.2: A-Arm Solid Model 


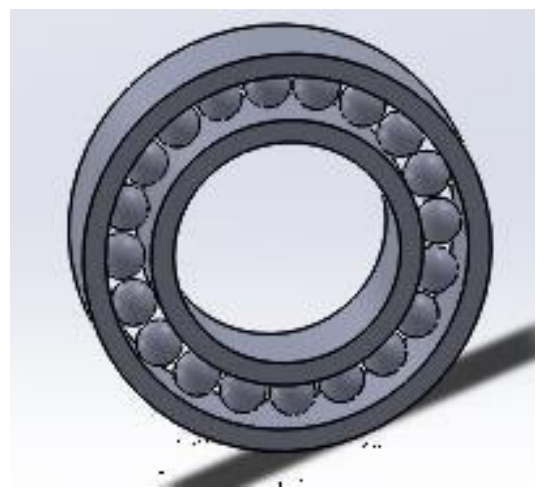

Figure 3.3: Ball bearing Solid Model

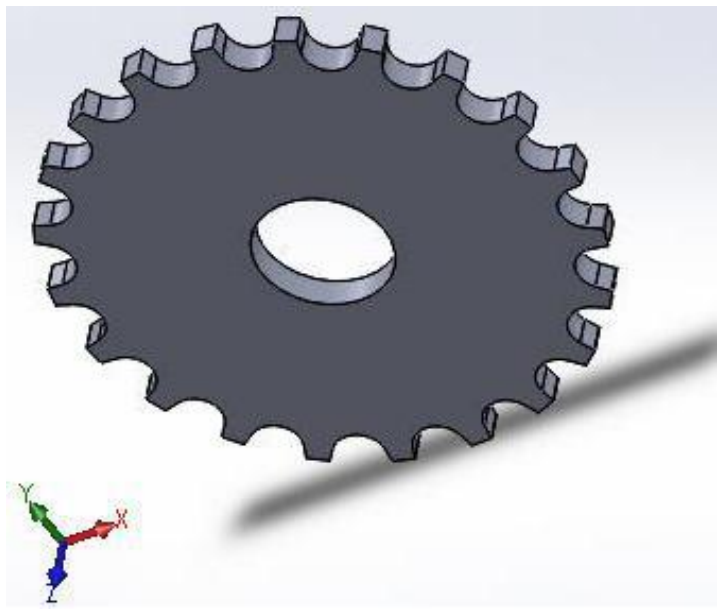

Figure 3.4: Sprocket Solid Model

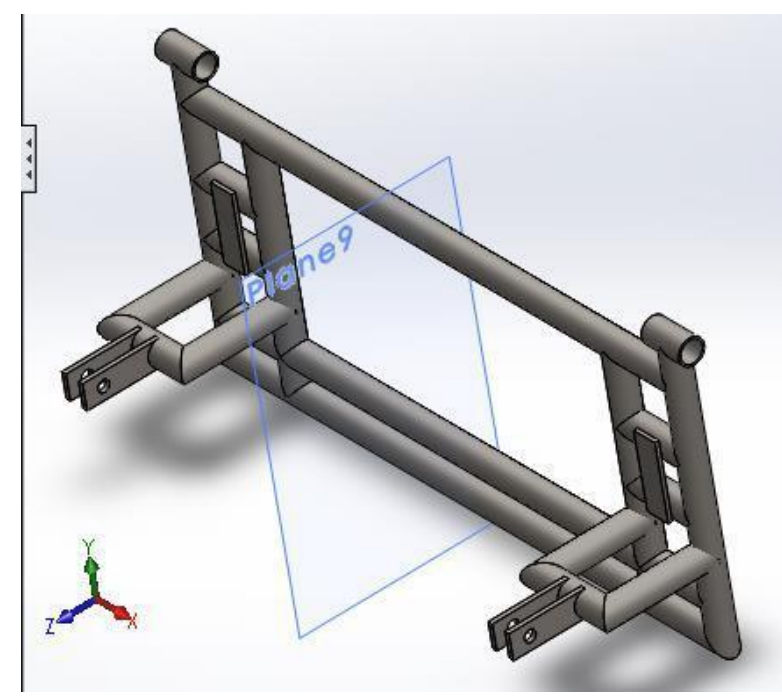

Figure 3.5: Trailing Arm Solid Model

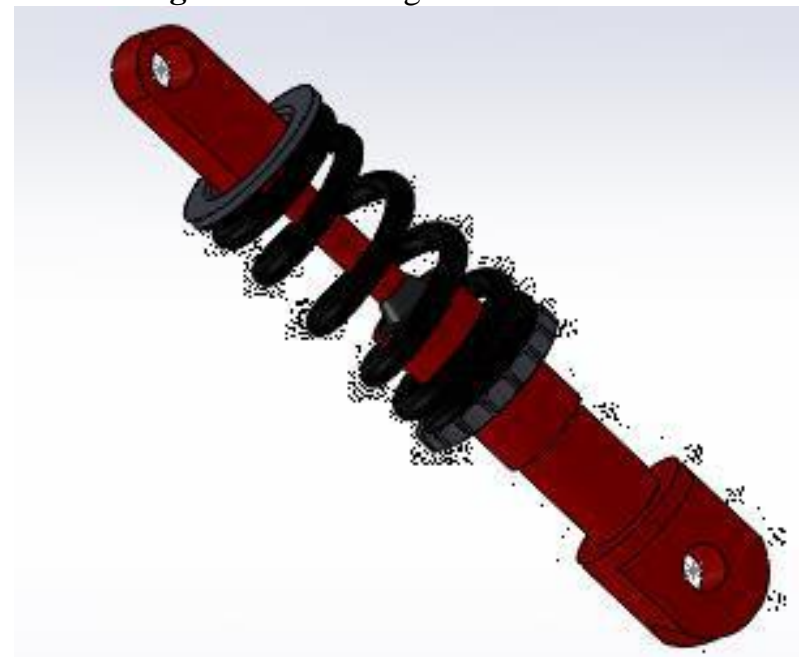

Figure 3.6: Suspension Solid Model

Then all the SolidWorks part documents were assembled and the following design was realized: 


\section{International Journal of Science and Research (IJSR) \\ ISSN (Online): 2319-7064}

Index Copernicus Value (2013): 6.14 | Impact Factor (2015): 6.391

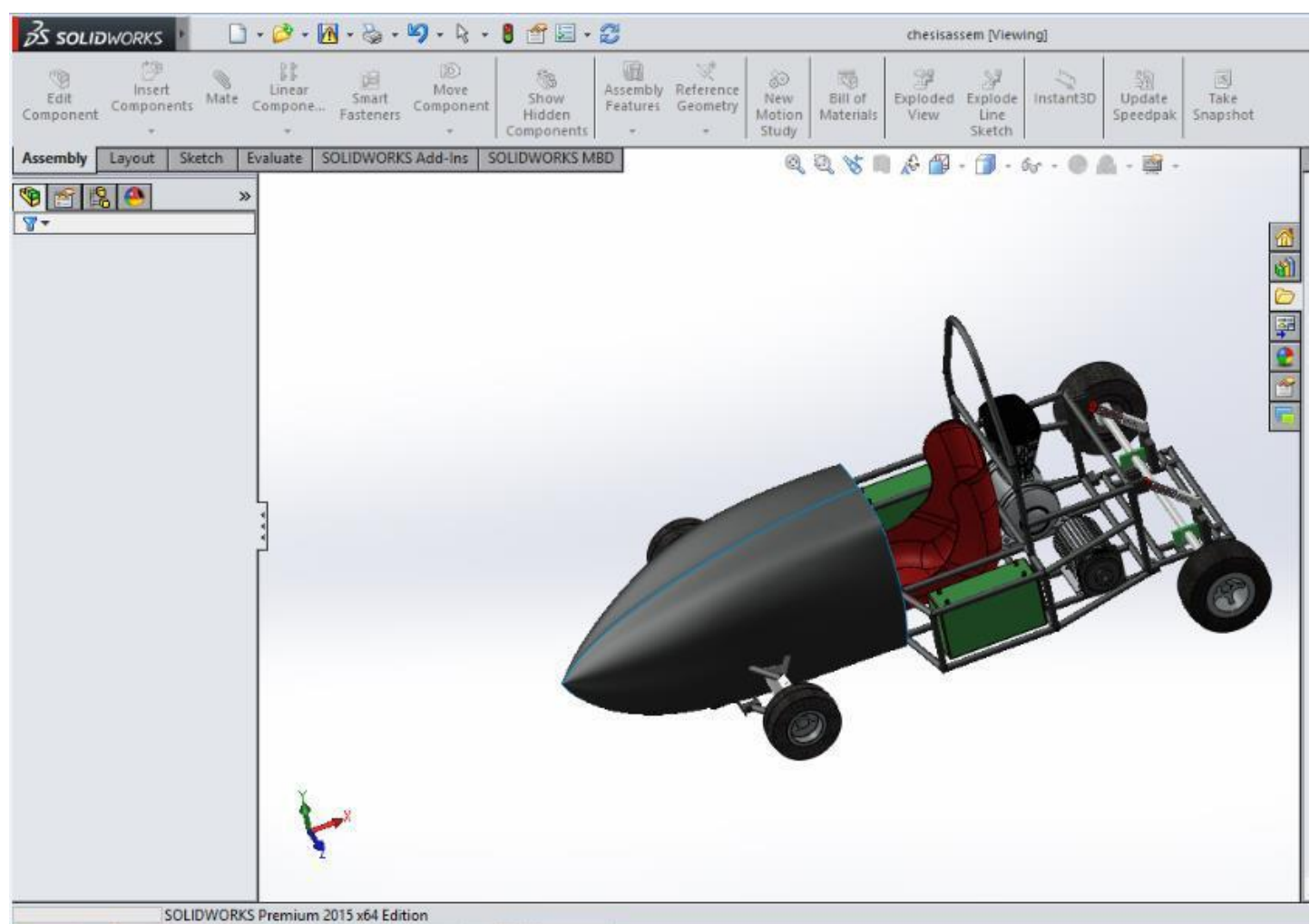

Figure 3.7: Hybrid Vehicle Design in SolidWorks

A rough sketch of the chassis was drawn on a sheet of paper and a PVC model was fabricated according to the layout of the vehicle. Then the go kart was manufactured using steel pipes. The pipes were cut in calculated dimensions using a circular saw and grooves were provided using a grinding machine. The pipes were then welded using mild steel electrodes using the Manual Metal Arc Welding (MMAW) technology to form a Space frames chassis. The space frame structure is strong owing to the rigidity of the triangles which enables flexing loads to be transmitted as compression and tension loads along the length of each strut.

The suspension, the engine, the motor and the body panels are fastened to the skeletal frame of steel tubes with brackets, and the body panels have no structural function. A petrol engine was used along with four batteries to run the electric motor to form a gasoline-electric hybrid. The wheels of the car were mounted to the chassis using Ackerman steering geometry because of its simplicity. Davis steering mechanism uses sliding joints which causes wear. Ackerman steering overcomes this problem as it uses revolute pairs which can be easily lubricated and thus causing lesser wear. The suspensions were mounted in a compressed position so as to accounts for the dents in the road. The front wheels had independent suspension while the back wheels were designed to have dependent ones. The steering system followed the Elliot Stub Axel setup. The suspension was stuck together with the main frame by a knuckle joint.

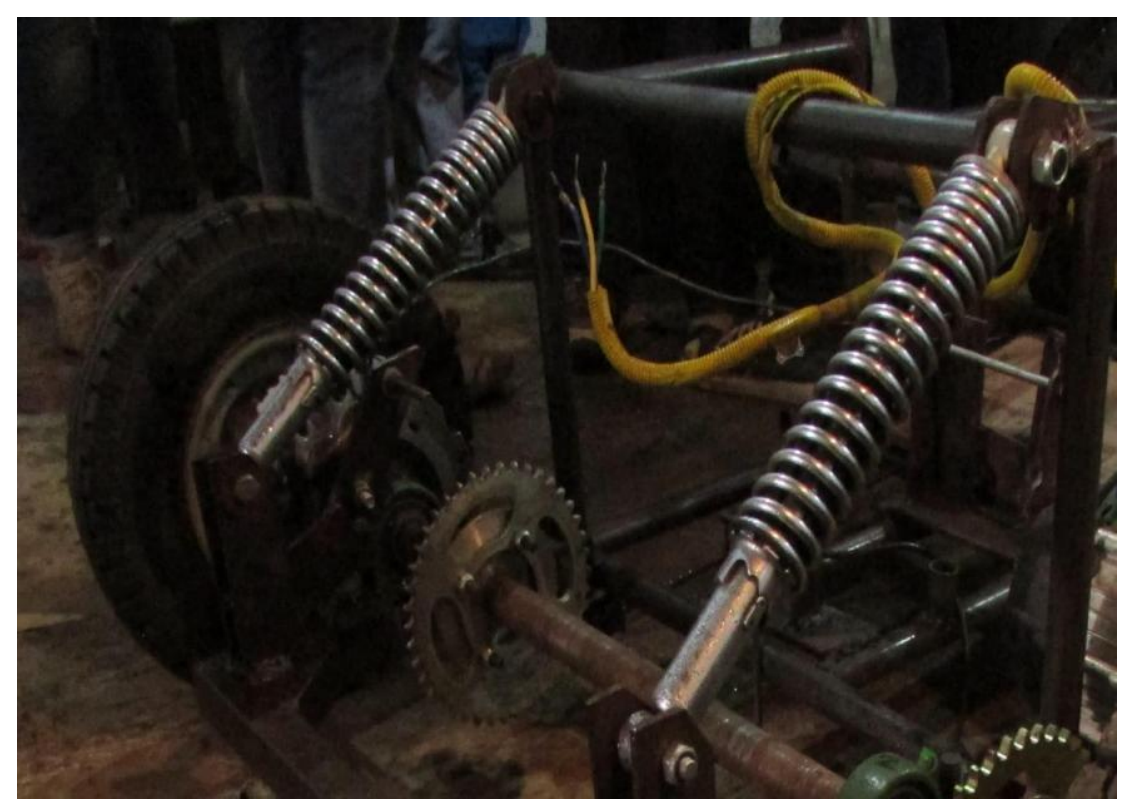

Figure 3.8: Knuckle Joint and Suspension System

Volume 5 Issue 10, October 2016 www.ijsr.net 


\section{International Journal of Science and Research (IJSR) \\ ISSN (Online): 2319-7064}

Index Copernicus Value (2013): 6.14 | Impact Factor (2015): 6.391

Disc brakes were used on the rear axle because it has 'linearity' and high torque transmitting capacity in small volume. The disc brakes are connected to the master cylinder via tubes and hoses. The brake fluid should be pure and it must not contain air bubbles. The disc brake system is based on Pascal's law of transmission of pressure in a confined fluid. The steering wheel was manufactured from steel pipes. The pipes were forged to shape by hammering. The roller chain was shortened by pulling out a pin from an appropriate position depending on the required length. It was then mated with the sprocket. The sprocket and chain were of standard dimensions. Rotational motion was transmitted from the engine to the rear wheels via roller chain and sprocket system. A dual ball bearing was used for each of the four wheels. Bearings supports the axle and ensures its free rotation. The rear axle was the live axle. Nickel-metal hydride was used to power the brushless DC induction type motor.

The reciprocating motion of the piston is converted to rotary motion by a slider-crank mechanism which then transmits the motion to a flywheel. The flywheel stores and releases energy when needed during the work cycle.

Table 1: Engine Specifications

\begin{tabular}{|c|c|}
\hline Engine & $\begin{array}{c}4 \text { Stroke, Single Cylinder, Air } \\
\text { Cooled }\end{array}$ \\
\hline Bore and Stroke & $57 \times 56.4$ \\
\hline Compression Ratio & 9.5:1 \\
\hline Maximum Power & 14.09 PS (10.35 KW) @8500rpm \\
\hline Maximum Torque & 12.76@6500rpm \\
\hline Transmission & 5 Speed, constant mesh \\
\hline Clutch & Multi-plate Wet \\
\hline Ignition & $\begin{array}{l}\text { CDI (Capacitor Discharge } \\
\text { Ignition) } \\
\end{array}$ \\
\hline Fuel Supply & Carburetor UCAL Mikuni BS29 \\
\hline Brake Power & $6.5 \mathrm{HP}$ \\
\hline Engine Displacement & 208 cc \\
\hline Start Type & Recoil and Electric \\
\hline
\end{tabular}

\begin{tabular}{|c|c|}
\hline Engine Type & OHV 950 Series \\
\hline Torque & $9.5 \mathrm{ft} / \mathrm{lbs}$ \\
\hline Shaft Output & Horizontal \\
\hline Crankshaft & Horizontal \\
\hline Shaft Diameter & $227 / 64$ inches \\
\hline Shaft Length & $3 / 16$ inches \\
\hline Shaft Keyway & $5 / 16$-24 tapped \\
\hline $\begin{array}{c}\text { Shaft end tapped } \\
\text { Diameter (in.)/ Threads } \\
\text { per inch) }\end{array}$ & $31 / 4$ qt \\
\hline Fuel Tank Capacity & No \\
\hline Fuel Pump & Yes \\
\hline Fuel Filter & $16-J a n$ \\
\hline Oil Capacity & Splash \\
\hline Lubrication System & Electronic \\
\hline Ignition System & Mechanical \\
\hline Governor System & Float \\
\hline Carburetor & Manual \\
\hline Throttle Control & Yes \\
\hline Choke Control & No \\
\hline Low Oil Alert & \\
\hline Low Oil Shutdown & Remote, Adjustable \\
\hline
\end{tabular}

Multiple Disk clutch comprises of two sets of disks. The first set is connected to the driven component via splines and they tend to move in an axial direction along the spline sleeve. Four bolts pass through the holes in the second set of disks which can also move in an axial direction because of the clearance fit between the holes and the bolt. Power is transmitted from the second set of disks to the first by means of friction. Clutches that are immersed in engine oil for cooling purposes are called wet clutches.

The inlet port of the engine is usually kept bigger than the outlet port. This is done to ensure that maximum volume of air enters the combustion chamber which in turn raises engine performance.

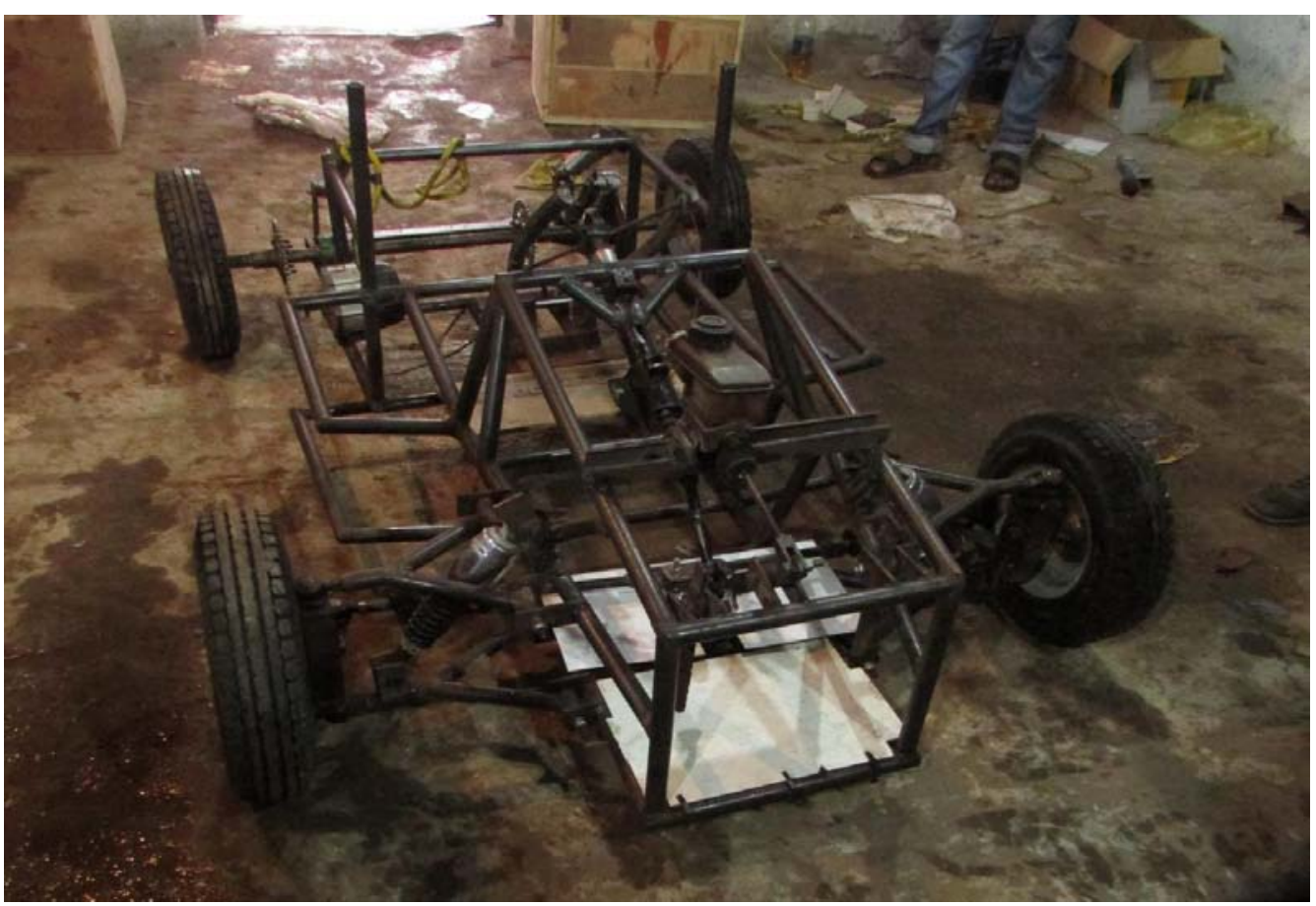

Figure 3.9: Steering System and Braking System

\section{Volume 5 Issue 10, October 2016 www.ijsr.net}

Licensed Under Creative Commons Attribution CC BY 


\section{Material Selection for A Hybrid Vehicle}

Material selection is important because the lighter the vehicle lesser is the energy needed to move it. Alloy steel (basically low alloy steel) pipes were used to form the chassis. Steel is tough and has high tensile and compression strength. Steel is divided up into a patchwork and each individual patch is a crystal. Inside these crystals are iron atoms which are arranged in a regular way. If zoomed out the crystals can be seen disrupted (as shown in the Fig. 4.1).

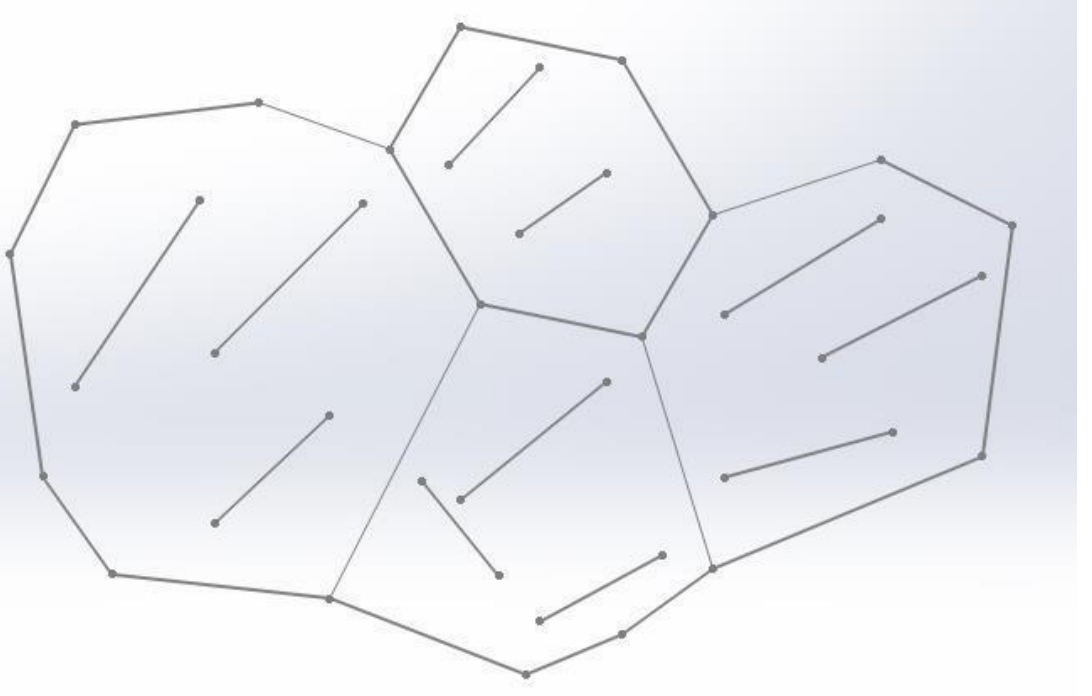

Figure 4.1: Schematic Diagram of Dislocations Inside Steel Crystal

These dislocations are what make steel crystal so special because they can move. When they move they change the shape of the crystal and thus they change the shape of steel. Thus, if steel is used as car body material its microstructure absorbs the shock energy in case of a crash and protects the passengers. The car body could have been made of carbon fiber and polymer mixture. The carbon fiber is lighter than steel so it saves energy. However, modern practices include the use of low carbon steels because of its excellent cold formability. But carbon fiber is expensive and molding it into parts is labor-intensive. Glass fiber is another material that is being used as car body material but glass fiber are damaged by water so steel with less than $0.1 \%$ carbon with up to $0.4 \%$ Manganese is used universally as car body. Electric Resistance Welded (ERW) pipes were used for building the chassis.

The shaft housing was of cast iron and the axle inside was made of medium carbon steel. The disc plate was of carbon ceramic matrix structure. The carbon ceramic discs weigh less, reduce unsprung mass, improve brake response, and have longer life than conventional discs. The master cylinder and the brake pedal were produced from aluminum owing to its lightweight. The brake linings were made of asbestos.

Brake caliper assembly is usually manufactured from aluminum or chrome-plated steel. Glycol-ether was used as brake fluid. Chrome moly steel was used to make the pushrods. The first set of disks of the multiple disk cutch system were made of hardened steel and the second set was of bronze.

The tires were made of carbon black and butyl rubber. Butyl rubber was used because of its low permeability to gas. Steel rims are used. The helical spring of the suspension system should be capable of withstanding resisting fatigue and high stresses. The springs were generally made from low percentage alloy-steels. The sprocket was of cast iron or carbon steel. Cast iron is cheap, heat resistant, has high compressive strength and negligible shrinkage. The chain was also made of the same material as the sprocket. The flooring was of galvanized sheet metal.

The flywheel, housing of the gearbox or engine has a complex shape. These parts are manufactured from cast iron because the casting processes produces complex shapes without involving much machining. Even the flywheel itself is made of cast iron. It is manufactured by centrifugal casting. In more recent times, flywheels are being made of high strength steels and composites. Modern car engines are increasingly using Graphite-Fiber Reinforced Polymer as flywheel material.

The gears inside the gearbox should be made from materials which has high yield stress. EN9 and EN24 steels are usually used for making gear pairs. The ball bearing was made of stainless steel. 


\section{International Journal of Science and Research (IJSR) \\ ISSN (Online): 2319-7064}

Index Copernicus Value (2013): 6.14 | Impact Factor (2015): 6.391

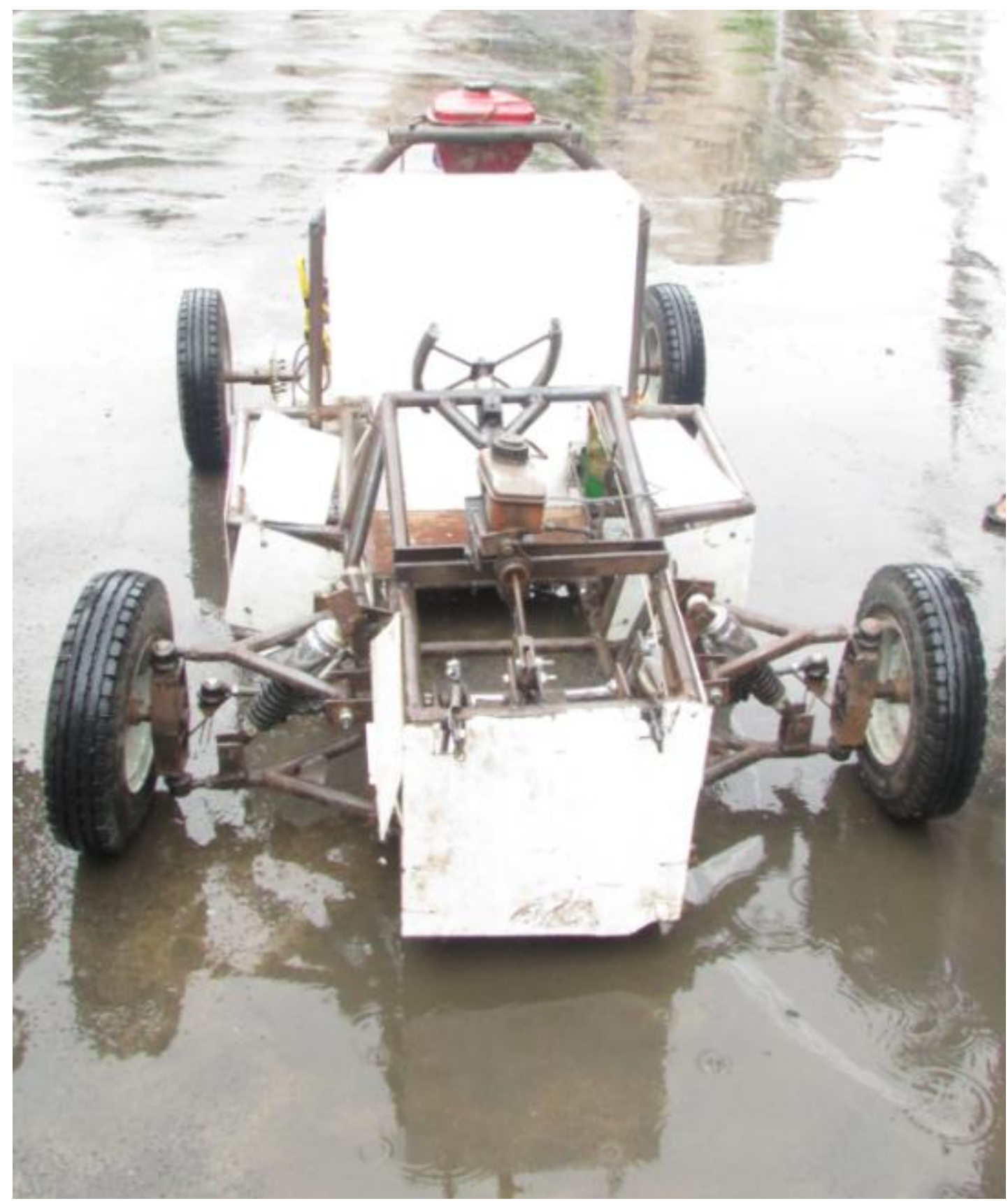

Figure 4.2: The Manufactured Hybrid Vehicle

The cylinder bore was of Aluminum with cast iron sleeve. The pistons were manufactured from cast aluminum alloy which are lightweight and have excellent thermal conductivity. The connecting rod and crank are subjected to fluctuating loads and $\mathrm{Ni}-\mathrm{Cr}$ steel was used for these components because of its higher resistance to fatigue strength. Due to the addition of Sulphur free cutting steels have excellent machinability and are suitable used for bolts and studs. 


\section{International Journal of Science and Research (IJSR) \\ ISSN (Online): 2319-7064}

Index Copernicus Value (2013): 6.14 | Impact Factor (2015): 6.391

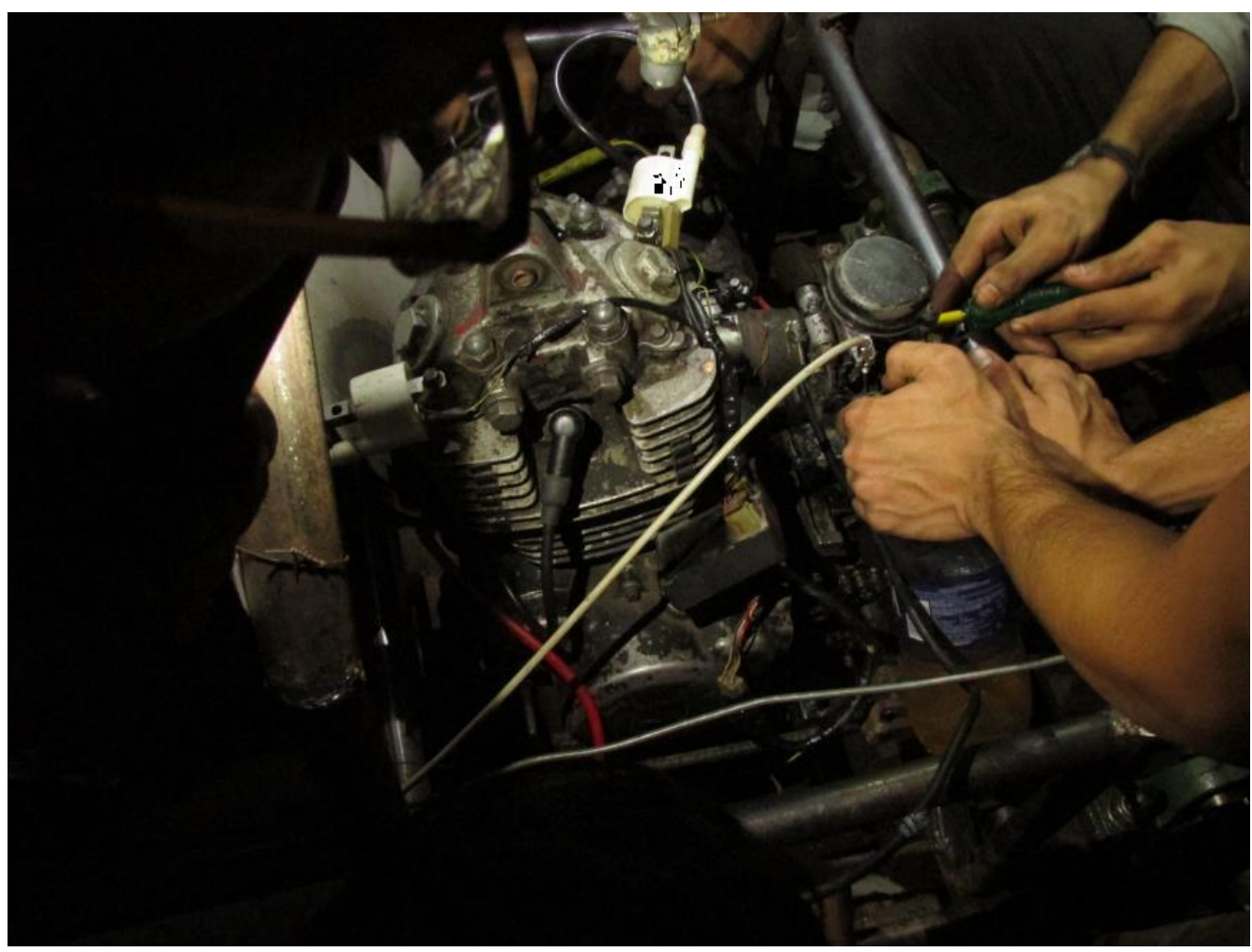

Figure 4.3: Engine

The three major materials of that carburetors are made of are: zinc, cast iron and aluminum. In the early 30's, cast iron started was substituted by zinc and by late 50's, aluminum substituted most of the zinc.

The most popular material used in carburetors is olive-green colored zinc. Zinc reacts with air and water form a powdery white material called the 'white rust'. To avoid this, carburetor parts are usually cured with a chromic acid solution that makes a thin zinc chromate covering on the surface. This is gives carburetors their green colour. However, carburetors are being increasingly replaced by fuel injectors which provide more accurate metering of air fuel ratio and thus increases fuel efficiency. But petrol injection is limited by its initial high cost, high maintenance cost and complex design.

The rotors of the motor move using an aluminum bar. The stator houses the conductor made from copper wires. The yoke is made of galvanized iron with rolled heat treatment. The commutators use carbon brushes. The motor housing is made of steel.

\section{Future Scope}

With the rapid advancements in technology, it is not hard to believe that hybrid cars are soon turning into the cars of the future. Popular automobile companies like Honda, Toyota, Mercedes, Ford, Volvo, BMW, Volkswagen and Ferrari are producing hybrid cars. Even Solar cells can also be installed in the framework to power the car in order to reduce fuel consumption. Another option is to use biofuels like cellulosic ethanol in vehicles. Ethanol or E85 is made from corn sugar and produces less greenhouse gases. Using Atkinson cycle engines can improve fuel economy. Almost half of the energy in the combustion chamber is lost to friction, as the piston rubs against the walls of the cylinder. Lubricants and piston geometry can be improved to minimize this loss. While designing a vehicle every surface should be streamlined to reduce drag. Rare earth elements such as dysprosium are required for the fabrication of battery systems and electric motors. Thus, increasing the production costs. The manufacturing of future hybrid cars should focus on less harmful emissions and increased efficiency.

Hybrid vehicles have also been developed which can charge its batteries from a wall socket. This connects the car to the electric grids so that it can get power from distant power plants. Compared to standard hybrids, the plug-in has more batteries and a larger motor but needs less space for the engine and fuel tank. Critics say that the pug-ins just shift the source of pollution from the tailpipe to the smokestack. But studies show that vehicles powered from today's mix of power plant could reduce greenhouse emissions by $40 \%{ }^{[10]}$. Further reduction are possible if cleaner electric power is used.

\section{Environmental Impact}

The hybrid vehicle offers great fuel efficiency and reduces pollution, emitting less greenhouse gases. Since these are eco-friendly vehicles, it uses NiMH batteries which can be recycled and releases no toxic or hazardous gases in the atmosphere and help in maintaining a green Earth. Unlike the internal-combustion engines (ICEs) in the conventional cars, the small size of the engine in hybrid vehicles have light weight, resulting in average power peak demands. In terms of noise, a hybrid vehicle makes much lesser noise in comparison to conventional gasoline or diesel powered cars. This may be due to substantial use of electric motors at low speeds.

\section{Volume 5 Issue 10, October 2016




\section{International Journal of Science and Research (IJSR) \\ ISSN (Online): 2319-7064}

Index Copernicus Value (2013): 6.14 | Impact Factor (2015): 6.391

\section{Conclusion}

The objective of the project was to construct a hybrid go kart with dual power source of gasoline engine and electric motor which can go at a speed of $60 \mathrm{kmph}$ which was successfully done. Researchers are constantly looking for new materials which can make a vehicle lighter and resists shocks during a crash. Solar panels can also be installed in a hybrid vehicle which will reduce the energy consumption but increase the initial cost. Vehicles having both an electrical charging battery system and a solar power charging system can be crucial when the weather is cloudy and at night. However, the overall cost of the vehicle should be as low as possible and the charging systems should be designed based on the end-user's requirements.

\section{Acknowledgments}

We, Sudipto Shekhor Mondol and Saswata Ghosh, would like to thank the members of Imperial Society of Innovative Engineers namely Abhishek Soni, Tarunesh Rajput, Anil Yadav and Shyam Prakash who were the heart and soul of this project. We would also like to thank Prof. Ritwik Mondal, Dr. Siddhartha Ray, Prof. Arup Jyoti Bhawal and many other faculty members of the department of mechanical engineering of Heritage Institute of Technology for their constant help and support. And lastly we would like to thank MYWBUT especially Mr. Binanjan Chatterjee (late) without whom this project won't have been possible.

\section{References}

[1] "Design of Machine Elements" by V B Bhandari, McGraw Hill Education, Third edition.

[2] Mariam Khan and Narayan C. Kar, "Hybrid Electric Vehicles for Sustainable Transportation: A Canadian Perspective" (World Electric Vehicle Journal Vol. 3 ISSN 2032-6653), Pages: 551- 562.

[3] "Internal Combustion Engines" by V. Ganesan, McGraw Hill Education, Fourth edition.

[4] Bharat M. Jibhakate, Rupesh Pandey, Deepak Sharma and Tejukumar Sah, "Study \& Modelling of Hybrid MILD Vehicle", International Journal for Scientific Research \& Development Vol. 3, Issue 01, 2015, Pages: 272-274.

[5] Abhishek C. Lad and A.S.Rao, "Design and Drawing Automation Using Solid Works Application Programming Interface", International Journal of Emerging Engineering Research and Technology Volume 2, Issue 7, Pages: 157-167.

[6] Hillier's Fundamentals of Motor Vehicle Technology, Book 1 by Victor Albert Walter Hillie.

[7] PP Dutta, M Dutta, D Das, A K Shukla, T K Gogoi and A Das, "Studies on Green Design \& Manufacture of Hybrid Vehicle", $5^{\text {th }}$ International \& 26th All India Manufacturing Technology, Design and Research Conference (AIMTDR 2014) December 12th-14th, 2014, IIT Guwahati, Assam, India.

[8] Juan Asensio-Lozano, Lorena Pérez-Redondas, María Ángeles García-García and José F. ÁlvarezAntolín, “A Materials Selection and Design Procedure for Selection of Automobile Vehicles that are Environmentally
Friendly in Terms of Available Energy Resources", Journal of Materials Education Vol. 34 (1-2): 1- 20 (2012), Pages: 1-19.

[9] S. L. Kampe, Proceedings of The 2001 Green Engineering Conference: Sustainable and Environmentally Conscious Engineering, Virginia Tech's College of Engineering and The US Environmental Agency, Pages: 7-1, 7-6

[10] "Car of the Future", Documentary, directed by Joseph Seamans, produced by Joseph Seamans and Janet Driscoll Smith.

\section{Author Profile}

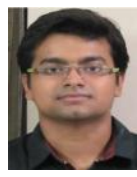

Sudipto Shekhor Mondol is in his seventh semester of Bachelor of Technology in Mechanical Engineering at Heritage Institute of Technology, Kolkata, India. His research interests lie in the field of welding technology, automotive engineering, fluid power control, production engineering, material handling and robotics.

Saswata Ghosh is currently in his seventh semester of Bachelor of Technology in Mechanical Engineering at Dr. Sudhir Chandra Sur Degree Engineering College, Kolkata, India. His research interests lies mainly in the field of automotive engineering and thermodynamics. 